\title{
The Transverse Topographic Symmetry Factor of Darakeh Stream in the North Tehran, Iran
}

\author{
Edvin Asatour Dizaj Takieh1", Manochehr Ghorashi' ${ }^{2}$, Fereydon Rezaie ${ }^{3}$ \\ ${ }^{1}$ Department of Geology, Science and Research Branch, Islamic Azad University, Tehran, Iran \\ ${ }^{2}$ Department of Geology, North Tehran Branch, Islamic Azad University, Tehran, Iran \\ ${ }^{3}$ Department of Applied Geology, Earth Science Institute, Geologic Survey of Iran, Tehran, Iran \\ Email: "edvin.asatour@gmail.com
}

Received 21 August 2015; accepted 21 November 2015; published 24 November 2015

Copyright (C) 2015 by authors and Scientific Research Publishing Inc.

This work is licensed under the Creative Commons Attribution International License (CC BY). http://creativecommons.org/licenses/by/4.0/

C) (i) Open Access

\begin{abstract}
The study area is located in the north Tehran, Iran. Calculation of transverse topographic symmetry factor ( $\mathrm{T}$ ) is suitable for rapid assessment of active tectonics. Therefore, transverse topographic symmetry factors have been calculated for the Darakeh stream. The study area is located in the Tehran Piedmont and transverse topographic symmetry factor is calculated for it. Based on values of this index, there is high relative tectonic activity level. This condition can be related to existence of a blind north-south striking fault which it may be buried by alluvium of the Darakeh stream. Dendritic drainage pattern of Darakeh stream and the fact that the western tributaries are longer than the eastern tributaries provide indirect evidence of ground tilting toward the east. Also, based on our results, most part of the study area have got high tectonic activity that it is compatible with its tectonic setting on the Tehran in north Iran.
\end{abstract}

\section{Keywords}

Transverse Topographic, Symmetry Factor, Darakeh, Tehran, Iran

\section{Introduction}

The Darakeh stream is located in the north Tehran, Iran (Figure 1). The Darakeh stream is located in the WestCentral Alborz and lesser Caucasus province (Figure 2). This area belongs to Tehran piedmont geologic unit [1]

\footnotetext{
"Corresponding author.
}

How to cite this paper: Takieh, E.A.D., Ghorashi, M. and Rezaie, F. (2015) The Transverse Topographic Symmetry Factor of Darakeh Stream in the North Tehran, Iran. Open Journal of Geology, 5, 770-779. 


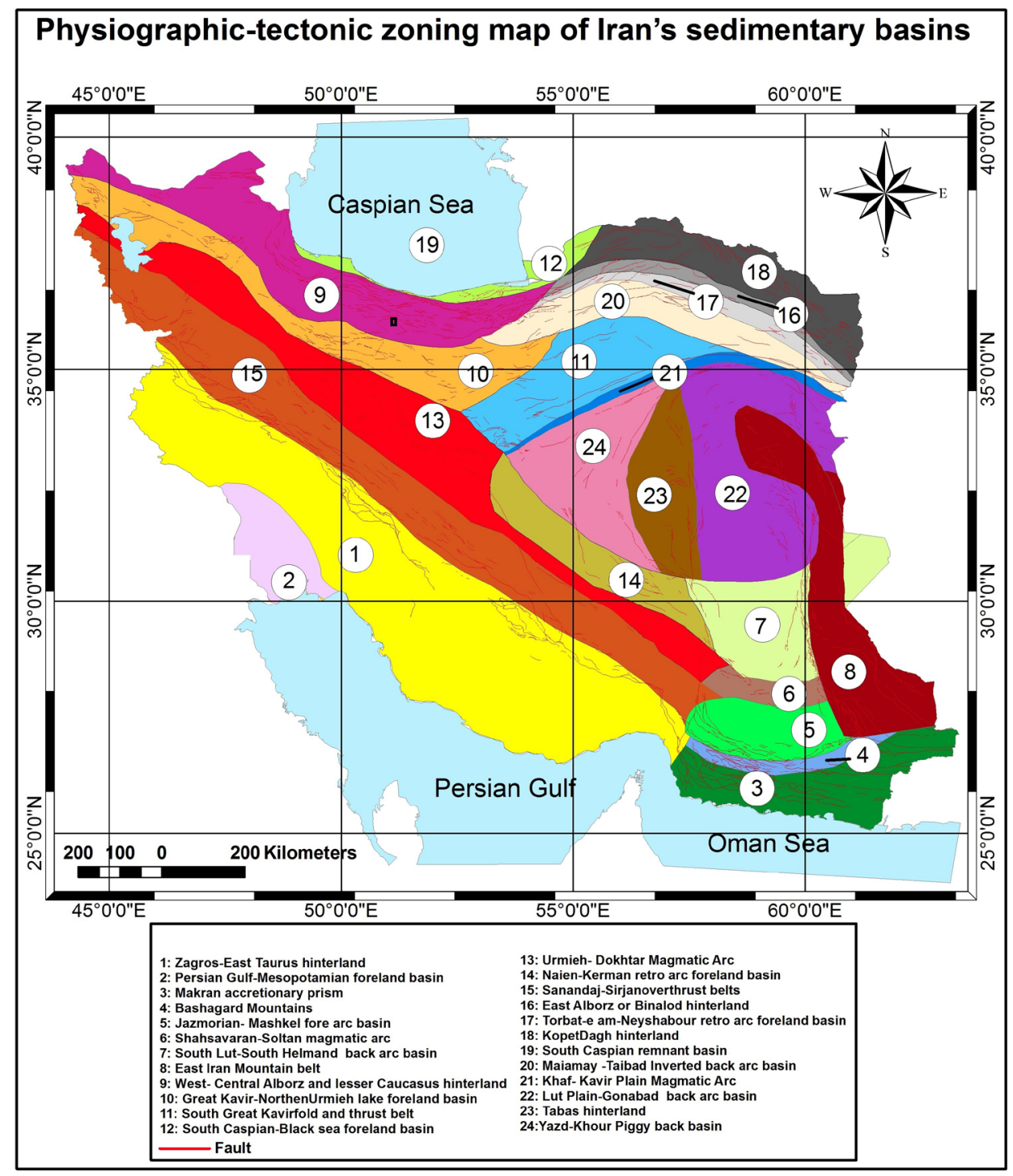

Figure 1. Physiographic-tectonic zoning map of Iran's sedimentary basins, modified from [1]. The study area is shown in the black rectangle.

[2]. Dominant structural trend in West-Central Alborz and lesser Caucasus province is NW-SE. From tectonics view, it contains deformed zone (fold and thrust belt) of Cimmerian miniplate that formed in northern active margin until late Triassic. Then it has rifted by tension in a back arc basin of Neotethyian subduction zone in the south margin of Cimmerian miniplate.

Development of that rift stopped in the late Cretaceous and then, renewed in the Eocene by spreading in submarine arc basin of Neotethyian subduction zone. In the other word, this hinterland is the result of a magmatic arc system spreading in the evolutional back arc basin. After that, West-Central Alborz and lesser Caucasus hinterland have formed by deformation and regional uplift from SW part of Caspian Sea to Black sea.

Recently, Damavand and Sebalan cones have formed by late volcanism that related to final subduction of Neotethyian oceanic slab toward north and northeast. Five dominant orogenic phases and four deformational events in Alborz Mountain building processes have suggested by [3].

The first deformational event is one from the Syn-collision type between Cimmerian-Eurasian plates (late Triassic) and the other ones are from post-collision deformational events and in with the deformational of sedimentary cover which is result of shortening and increasing the thickness of active continental crust in north of Cimmerian miniplate. 


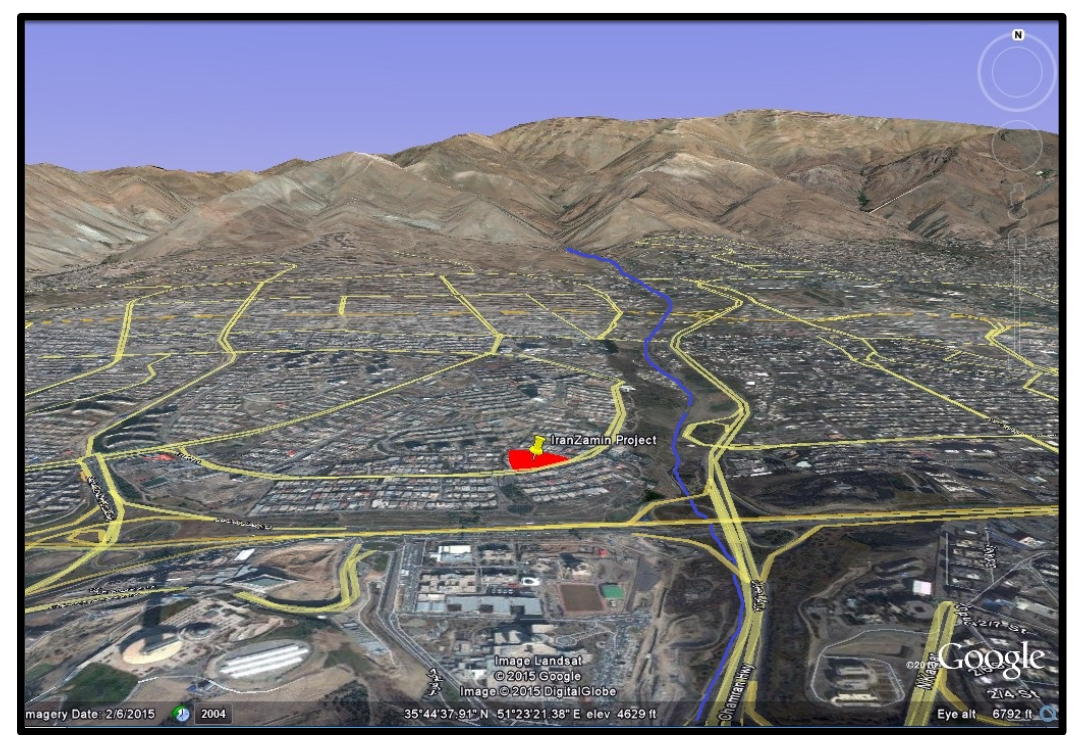

Figure 2. The Darakeh stream (blue line) and Iranzamin construction project (red part) on Shahrak-e Ghods in the North Tehran, based on Google earth (2015).

Based on previous work on the salt and mud diapirism [4]-[15] and neotectonic regime in Iran [16]-[21], Zagros in south Iran is the most active zone [22]-[44]. Then, Alborz [45]-[84] and Central Iran [85]-[100] have been situated in the next orders.

\section{Materials and Methods}

The calculation of transverse topographic symmetry factor $(\mathrm{T})$ is suitable for rapid assessment of active tectonics. Therefore, transverse topographic symmetry factors have calculated for the Darakeh stream. Based on digital elevation model, there is a north-south sub-basin. The study area is located between longitudes E51 $22^{\prime}$ $\mathrm{E} 51^{\circ} 25^{\prime}$ and latitudes $\mathrm{N} 35^{\circ} 44^{\prime}-\mathrm{N} 35^{\circ} 48^{\prime}$ in the Tehran province, in the north of Iran.

\section{Transverse Topographic Symmetry Factor (T)}

The transverse topographic symmetry factor $(T)$ was calculated as follows: $\mathrm{T}=\mathrm{Da} / \mathrm{Dd}$.

Which Da is the space from the midline of the drainage basin to the midline of the active belt and Dd is the space from the midline to the basin limit [101]. In a completely symmetric basin $\mathrm{T}=0$ and as asymmetry increases $\mathrm{T}$ approaches to value of 1.0 [102]. Two views from an open pit (red part in Figure 2) at the west of the Darakeh stream that used for construction project have presented in Figure 3.

Finally, we can consider class 1 for $\mathrm{T}>0.4$ in the study area that shows high relative tectonic activity (Table 1).

\section{Results and Discussion}

There is high level of active tectonics and this situation can be related to the main blind fault such as Iranzamin fault. This fault that is cropping out in the open pit (Figure 4) has introduced in this paper for the first time. Iranzamin fault with nearly east-west strike, $60^{\circ}$ dip toward the north and 2.5 meters dip separation has cut the Hezardareh (A) alluvial formation. This formation has got $45^{\circ}$ dip toward the north and possibly, it has cropped out associated with development of a piggyback basin in front of the north Tehran fault.

This area has located in sub-basin no. 27, based on a new classification [103] that is shows the highest relative tectonic activities. Therefore, our results based on calculation of $\mathrm{T}$ index are compatible with evaluation results of relative tectonic activity by other geomorphic indices. According to these researches, the study area has got the highest relative tectonic activities in the Tehran region. This situation may be related to existence of a blind normal north-south striking fault, under the western border of Darakeh stream valley. Darakeh stream has got dendritic drainage pattern (Figure 5) which the western tributaries are longer than the eastern tributaries and it 


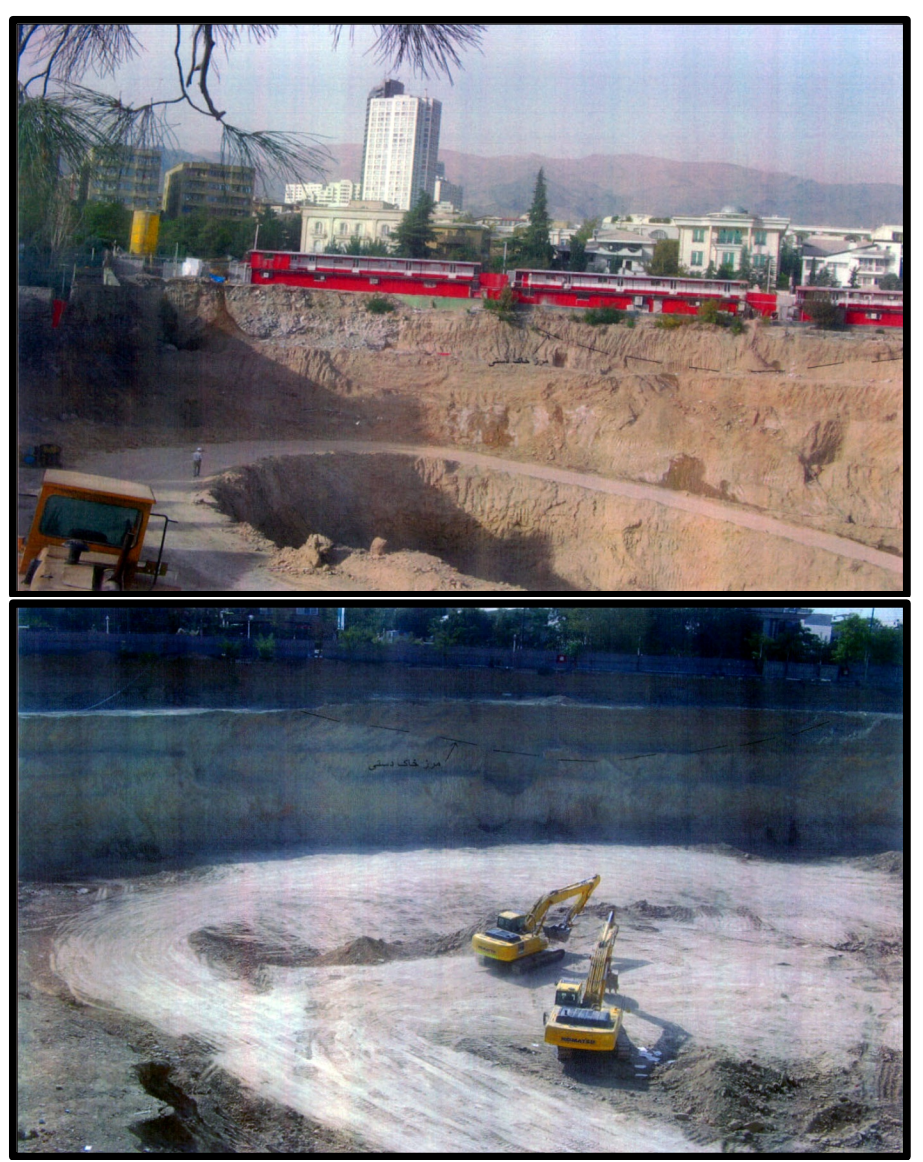

Figure 3. Two view from the open pit of Iranzamin construction project in the Shahrak-e Ghods at the west of the Darakeh stream.

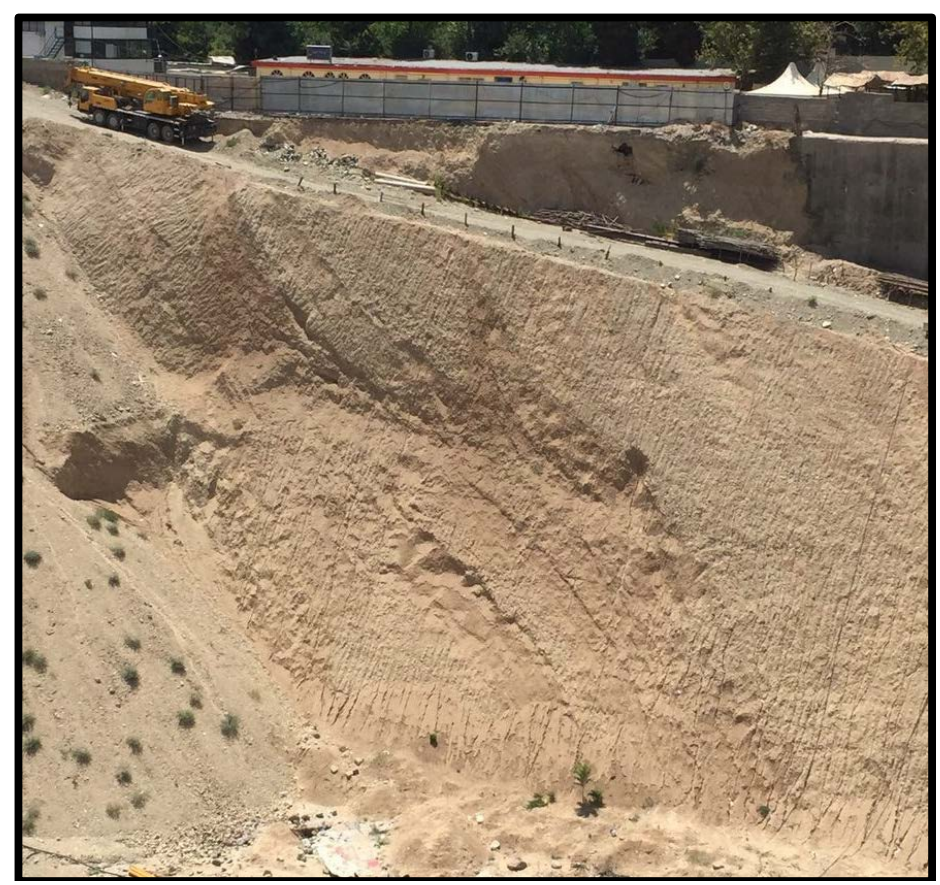

Figure 4. A view from the Iranzamin fault in the Shahrak-e Ghods open pit. 


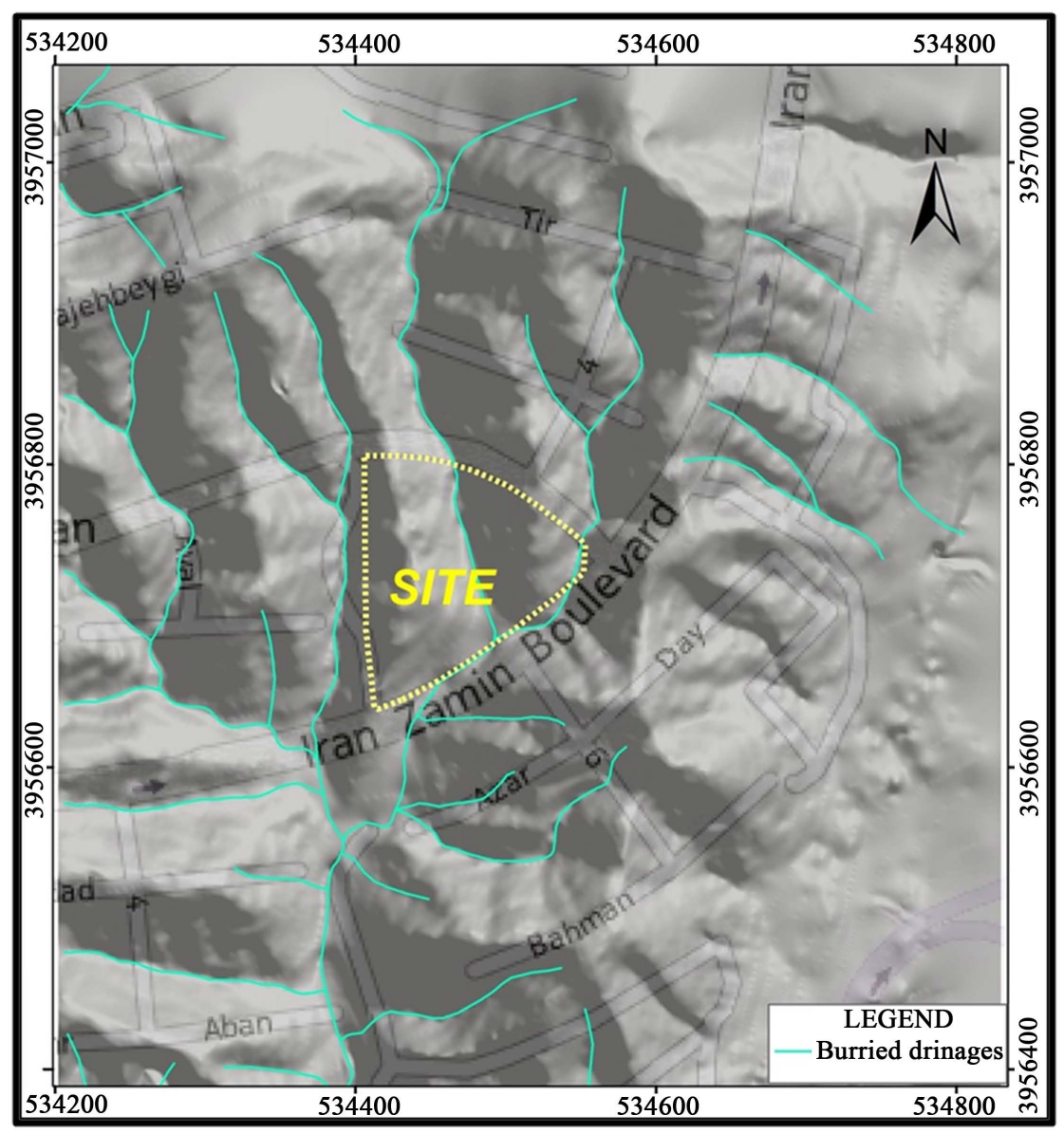

Figure 5. A part of aerial photograph related to 1963 from the site of Iranzamin construction project in the Shahrak-e Ghods, Tehran that shows dendritic drainage pattern of Darakeh stream.

Table 1. Values of T index for Darakeh basin.

\begin{tabular}{cccccc}
\hline Number & Da $(\mathrm{m})$ & $\mathrm{Dd}(\mathrm{m})$ & $\mathrm{T}(\mathrm{m})$ & $\mathrm{T}_{\text {ave }}(\mathrm{m})$ & Tectonic class \\
\hline 1 & 577 & 2281 & 0.25 & & \\
2 & 1214 & 1497 & 0.81 & & 1 \\
3 & 2029 & 3929 & 0.52 & 0.53 & \\
4 & 568 & 997.3 & 0.57 & & \\
\hline
\end{tabular}

shows a possible evidence of ground tilting toward the east. This tilting can be result of dip slip activity of above mentioned normal fault with the west dip direction.

\section{Conclusions}

Calculation of transverse topographic symmetry factor (T) is suitable for rapid assessment of active tectonics. The $\mathrm{T}$ index has been calculated in the Darakeh stream in the north Tehran, Iran.

The study area is located in the Tehran Piedmont and transverse topographic symmetry factor is calculated for it. Based on values of this index, there is high relative tectonic activities level. This condition can be related to existence of a blind normal north-south striking fault which may be buried by alluvium of the Darakeh stream. Dendritic drainage pattern of Darakeh stream and the fact that the western tributaries are longer than the eastern tributaries provide indirect evidence of ground tilting toward the east. 


\section{Acknowledgements}

This work has been funded by the Department of geology, Islamic Azad University, Science and Research branch, Tehran, Iran. Also, special thanks to Dr. Arian and vice-president for research in Science and Research branch, Tehran.

\section{References}

[1] Arian, M. (2013) Physiographic-Tectonic Zoning of Iran’s Sedimentary Basins. Open Journal of Geology, 3, $169-177$. http://dx.doi.org/10.4236/ojg.2013.33020

[2] Qorashi, M. and Arian, M. (2011) Tectonics of Iran. Geologic Survey of Iran, Tehran, 336 p.

[3] Arian, M. (2011) Basement Tectonics and Geology of Iran. Asar Nafis Press, Qum, 300 p.

[4] Arian, M. (2011) A Preface on Salt Diapirism of Iran. Asar Nafis Press, Qum, 309 p.

[5] Arian, M. and Noroozpour, H. (2015) The Biggest Salt-Tongue Canopy of Central Iran. Open Journal of Geology, 5, 55-60. http://dx.doi.org/10.4236/ojg.2015.52005

[6] Asadian, F., Pourkermani, M. and Arian, M. (2007) Tectonic Geomorphology of Salt Structures in the GarmsarLasjerd Area. Geographical Research, 39, 75-84.

[7] Pourkermani, M. and Arian, M. (1997) Salt Domes of Central Iran. Journal of Humanities, 3, 29-41.

[8] Arian, M. (2012) Salt Diapirism and Tectonics. Second Edition, Asar Nafis Press, Qum, 319 p.

[9] Arian, M. and Noroozpour, H. (2015) Tectonic Geomorphology of Iran’s Salt Structures. Open Journal of Geology, 5, 61-72. http://dx.doi.org/10.4236/ojg.2015.52006

[10] Asadian, F. and Arian, M. (2009) Identification of Diapiric Provinces of Central Iran through Geological and Geographical Analysis. International Journal of Agriculture Environment \& Biotechnology, 2, 3443-3451.

[11] Arian, M. (2012) Clustering of Diapiric Provinces in the Central Iran Basin. Carbonates and Evaporites, 27, 9-18. http://dx.doi.org/10.1007/s13146-011-0079-9

[12] Pourkermani, M. and Arian, M. (1998) Tectonic Geomorphology of Salt Domes in West of Zanjan Province, Iran. Geographical Research, 47, 44-53.

[13] Arian, M. and Feizi, F. (2010) The Significance of Faulting on the Surficial Spreading of Evaporitic Deposits in the Varamin-Semnan Area. Journal of Earth and Resources, 3, 1-20.

[14] Feizi, F., Arian, M. and Arian, A. (2015) Mud Diapirism on the Makran, Iran: Case Study on the Napag Mud Volcano. Open Journal of Geology, 5, 300-308. http://dx.doi.org/10.4236/ojg.2015.55027

[15] Arian, M. and Sistanipour, A. (2015) Mud Diapirism on the Gorgan, North Iran. Open Journal of Geology, 5, $442-450$. http://dx.doi.org/10.4236/ojg.2015.56041

[16] Arian, M. and Khodabakhshnezhad, A. (2015) Sedimentary Environments Can Be Changed by Geotechnology (Case Study: A Morphotectonic Idea for Design of Extensive Artificial Bay on the Iranian Plateau). International Journal of Geosciences, 6, 487-496. http://dx.doi.org/10.4236/ijg.2015.65039

[17] Arian, M. (2011) Middle East Tectonics. Asar Nafis Press, Qum, 236 p.

[18] Arian, M. (2010) Applied Seismotectonics. Farazamin Press, Tehran, 304 p.

[19] Arian, M. and Maleki, R. (2008) Neotectonics. Farazamin Research Center, Tehran, 150 p.

[20] Pourkermani, M. and Arian, M. (1998) Seismicity of Iran. Shahid Beheshti University Press, Tehran, 212 p.

[21] Pourkermani, M. and Arian, M. (1997) Seismotectonics. Dez Ab Consulting Engineers Company Press, Tehran, 270 p.

[22] Arian, M. and Aram, Z. (2014) Relative Tectonic Activity Classification in the Kermanshah Area, Western Iran. Solid Earth, 5, 1277-1291. http://dx.doi.org/10.5194/se-5-1277-2014

[23] Mashal, M., PourKermani, M., Charchi, A., Almasian, M. and Arian, M. (2013) Pattern of Structural Geology Underground in Eastern of North Dezfol Embayment. Advances in Environmental Biology, 7, 260-268.

[24] Pazhoohan, M., Arian, M., Ghorashi, M. and Khosrotehrani, K. (2014) A Study of Drainage Pattern Responses to Active Tectonics in Tadvan Region, SW Iran. Geodynamics, 1, 36-41.

[25] Rahimi, N. and Arian, M. (2014) Tectonic Geomorphplogy of Kangavar-Sosangerd Region, West Iran. Advances in Environmental Biology, 8, 119-124.

[26] Arian, M. and Hashemi, A. (2008) Seismotectonic Zoning in the Zagros. Journal of Sciences, 18, 63-76.

[27] Arian, M., Ahmadnia, A., Qorashi, M. and Pourkermani, M. (2002) Structural Analysis of Mengharak Transcurrent Fault System in Zagros, Iran. Special Geo 2002 Conference Issue Geoarabia, 7, 209-210. 
[28] Arian, M., Qorashi, M. Pourkermani, M. and Ahmadnia, A. (2003) Fractal Analysis of Mengharak Transcurrent Fault System in Zagros, Iran. Abstracts of 4th International Conference on Seismology and Earthquake Engineering, Tehran, 12-14 May 2003, 23.

[29] Baharvand, S., Pourkermani, M., Ajalloian, R., Arian, M. and Nouryazdan, A.R. (2010) Seymareh Landslide and Its Role in Environmental and Geomorphologic Changes of the Pole-Dokhtar Area. Journal of the Earth, 4, 13-24.

[30] Abdideh, M., Qorashi, M., Rangzan, K. and Arian, M. (2011) Assessment of Relative Active Tectonics Using Morphometric Analysis, Case Study of Dez River (Southwestern, Iran). Geosciences, 20, 33-46.

[31] Arian, M., Qorashi, M., Pourkermani, M. and Ahmadnia, A. (2006) The Structural Significance Kareh Bas Transcurrent Fault System in the Zagros Fold and Thrust Belt. Geosciences, 15, 126-133.

[32] Arian, M. and Noroozpour, H. (2015) Seismic Activity and Fractal Geometry of Kareh Bas Fault System in Zagros, South of Iran. Open Journal of Geology, 5, 291-299. http://dx.doi.org/10.4236/ojg.2015.55026

[33] Ehsani, J. and Arian, M. (2015) Quantitative Analysis of Relative Tectonic Activity in the Jarahi-Hendijan Basin Area, Zagros Iran. Geosciences Journal, 19, 1-15. http://dx.doi.org/10.1007/s12303-015-0016-3

[34] Omidali, M., Arian, M. and Sorbi, A. (2015) Neotectonics of Boroujerd Area, SW Iran by Index of Active Tectonics. Open Journal of Geology, 5, 309-324. http://dx.doi.org/10.4236/ojg.2015.55028

[35] Chegini, A., Sorbi, A. and Arian, M. (2015) Active Tectonics of Hamedan Area, West Iran. International Journal of Geography and Geology, 4, 109-128.

[36] Maleki, Z., Arian, M., Solgi, A. and Ganjavian, M.A. (2014) The Elements of Fold Style Analysis in the Khaftar Anticline, Zagros, Iran. Open Journal of Geology, 4, 79-92. http://dx.doi.org/10.4236/ojg.2014.43008

[37] Maleki, Z., Arian, M. and Solgi, A (2014) Structural Style and Hydrocarbon Trap of Karbasi Anticline, in the Interior Fars Region, Zagros, Iran. Solid Earth Discussions, 6, 2143-2167. http://dx.doi.org/10.5194/sed-6-2143-2014

[38] Ehsani, J., Arian, M. and Ghorashi, M. (2015) Geomorphic Signatures of Active Tectonics in the Jarahi-Hendijan Drainage Basin in the South West Iran. Geosciences, 24, 211-218.

[39] Khodabakhshnezhad, A., Pourkermani, M., Arian, M., Matkan, A.A. and Charchi, A. (2015) Active Tectonics of Great Karoun River Basin. Geosciences, 24, 13-28.

[40] Maleki, Z., Arian, M., Solgi, A. and Ganjavian, M.A. (2015) Elements of Fold Style Analysis in the Karbasi Anticline, Interior Fars Region, Zagros. Geosciences, 24, 293-302.

[41] Baratpour, F., Arian, M. and Solgi, A. (2015) Geometric Analysis of Tukak and Kamarun Anticlines on Izeh Zone, Zagros. Geosciences, 24, 191-200.

[42] Gholamhosein Fard, N., Sorbi, A. and Arian, M. (2015) Active Tectonics of Kangavar Area, West Iran. Open Journal of Geology, 5, 422-441. http://dx.doi.org/10.4236/ojg.2015.56040

[43] Maleki, Z., Arian, M. and Solgi, A. (2015) Folding Pattern in the Fars Province, Zagros Folded Belt: Case Study on the Karbasi and Khaftar Anticlines, Interior Fars, Iran. Solid Earth Discuss, 7, 2347-2379.

[44] Razaghian, G. and Arian, M. (2015) The Emergent Salt Diapirs in the East Zagros, Iran. Open Journal of Geology, 5, 718-726. http://dx.doi.org/10.4236/ojg.2015.510063

[45] Alladin, Y., Talebian, M., Arian, M. and Ahmadi, M.M. (2015) Geotechnical Investigation and Seismic Zonation of Alluvial Deposits in Western Tehran. Geosciences, 24, 333-342.

[46] Taherkhani, B., Nazari, H., Pourkermani, M. and Arian, M. (2015) Geometry and Recent Kinematics of the North Qazvin Fault: Morphotectonic Approach. Geosciences, 24, 29-38.

[47] Haj Manuchehri, M. Arian, M., Ghorashi, M., Solgi, M. and Sorbi, A. (2015) Geomorphic Signatures of Active Tectonics in the Chalus Drainage Basin in the Alborz, Iran. Geosciences, 24, 273-280.

[48] Noroozpour, H., Arian, M. and Sorbi, A. (2015) Fault Movement Potentials in the Tehran-Semnan Region (North Iran). Open Journal of Geology, 5, 281-290. http://dx.doi.org/10.4236/ojg.2015.55025

[49] Arian, M., Maleki, Z. and Noroozpour, H. (2011) Cenozoic Diastrophism and Deformational Events in the East Central Alborz. Journal of Basic and Applied Scientific Research, 1, 2394-2400.

[50] Feizi, F., Arian, A. and Rahmani, R. (2007) Seismotectonic Zoning in the Eastern Part of the Central Alborz. Journal of Sciences, 17, 151-164.

[51] Khavari, R., Arian, M. and Ghorashi, M. (2009) Neotectonics of the South Central Alborz Drainage Basin, in NW Tehran, N Iran. Journal of Applied Sciences, 9, 4115-4126. http://dx.doi.org/10.3923/jas.2009.4115.4126

[52] Arian, M. and Bagha, N. (2012) Active Tectonics of Tehran Area, Iran. Journal of Basic and Applied Scientific Research, 2, 3805-3819.

[53] Sadeghi, R., Saeedi, A., Arian, M., Ghorashi, M. and Solgi, A. (2015) Comparison of Strain Ellipsoid Shape in the 
South of Ardabil Range (NW), Based on the Results of the Magnetic Susceptibility Anisotropy and Paleostress Methods. Open Journal of Geology, 5, 611-622. http://dx.doi.org/10.4236/ojg.2015.59054

[54] Arian, M. and Feizi, F. (2005) Application of Geomorphic Indices to the Assessment of Relative Tectonic Activity Levels in the Alborz-Central Iran Border Zone. Journal of Sciences, 15, 378-403.

[55] Arian, M., Bagha, N., Khavari, R. and Noroozpour, H. (2012) Seismic Sources and Neo-Tectonics of Tehran Area (North Iran). Indian Journal of Science and Technology, 5, 2379-2383.

[56] Moghimi, H., Arian, M. and Sorbi, A. (2015) Fault Movement Potential of Marzanabad Area, North Alborz, Iran. Open Journal of Geology, 5, 126-135. http://dx.doi.org/10.4236/ojg.2015.53012

[57] Arian, M. and Pourkermani, M. (2004) Tectonic Elements of South Flank in the East-Central Alborz Mountain. Journal of Sciences, Teacher Training University, 4, 359-368.

[58] Arian, M. and Qorashi, M. (2006) The Movement Potential Evaluation of the Major Quaternary Faults in Alborz-Central Iran Border Zone, from the East of Tehran to the East of Semnan. Journal of Geosciences, Geological Survey of Iran, 15, 184-188.

[59] Poroohan, N., Pourkermani, M. and Arian, M. (2013) An Assessment of Relationship in F-Parameter and Paleostress Fields in Heterogeneous Lithologies: Roudbar Area (Northwest of Iran). Australian Journal of Basic \& Applied Sciences, 7, 933-942.

[60] Poroohan, N., Poukermani, M. and Arian, M. (2009) An Assessment on Correlations of Seismotectonic Parameters Preceding and Following Roudbar-Manjil Earthquake (Gilan, North of Iran). Australian Journal of Basic \& Applied Sciences, 3, 2643-2652.

[61] Farrokhnia, A.R., Pirasteh, S., Pourkermani, M. and Arian, M. (2011) Geo-Information Technology for Mass Wasting Hazard Zonation: Central-West Alborz-Iran. Disaster Advances, 4, 24-33.

[62] Khavari, R., Ghorashi, M. and Arian, M. (2009) Assessment of Relative Active Tectonics, South Central Alborz (North Iran). EGU General Assembly Conference, Vienna, 19-24 April 2009, 1137.

[63] Sorbi, A., Arian, M. and Pourkermani, M. (2009) The Movement Potential Evaluation of the Major Quaternary Faults in Tehran Quadrangle. Journal of the Earth, 19, 176-182.

[64] Feizi, F. and Arian, M. (2006) The Classification of Thrust Fronts in the Alborz-Central Iran Border Zone from the East of Varamin to the East of Semnan. Journal of Sciences, 16, 75-87.

[65] Pahlavani, A., Pourkermani, M., Arian, M. and Vahabzadeh, G. (2010) Structural Analysis of Emaft Fluorite Mine Region (SavaadKuh Mazandaran). Journal of the Earth, 5, 75-81.

[66] Arian, M. and Pourkermani, M. (2004) Structural Significance of North Semnan and Attary Faults in Alborz-Central Iran Border Zone. Journal of Science, 14, 4551-4569.

[67] Arian, M. and Pourkermani, M. (2005) Cenozoic Diastrophism and Deformational Events in the Southern Flank of Central-East Alborz. Journal of Faculty Earth Sciences, 10, 43-51.

[68] Arian, M., Pourkermani, M., Qorashi, M. and Ghasemi, M.R. (2003) North Semnan Fault System and Its Role on Basin Division. 8th Symposium of Geological Society of Iran, Shahrood University of Technology, 4-6 September 2003, 11-17.

[69] Pourkermani, M. and Arian, M. (2001) Structural Geomorphology of Northeastern Kurdistan. Journal of Humanities, 7, 37-48.

[70] Mardani, Z., Ghorashi, M. and Arian, M. (2011) Geomorphic Signatures of Active Tectonics in the Talaghan Rud, ShahRud and Sefidrud Drainage Basins in Central Alborz, N Iran. Geosciences, 20, 159-166.

[71] Sorbi, A., Arian, M. and Pourkermani, M. (2011) The Application of Geomorphic Indices to the Assessment of Relative Tectonic Activity Levels in Tehran Quadrangle. Journal of the Earth, 6, 1-9.

[72] Khavari, R., Ghorashi, M., Arian, M. and Khosrotehrani, K. (2010) Geomorphic Signatures of Active Tectonics in the Karaj Drainage Basin in South Central Alborz, N, Iran. Geosciences, 19, 67-74.

[73] Javadi Mousavi, E. and Arian, M. (2015) Tectonic Geomorphology of Atrak River, NE Iran. Open Journal of Geology, 5, 106-114. http://dx.doi.org/10.4236/ojg.2015.53010

[74] Nouri, R., Jafari, M.R., Arian, M., Feizi, F. and Afzal, P. (2013) Correlation between Cu Mineralization and Major Faults Using Multifractal Modelling in the Tarom Area (NW Iran). Geologica Carpathica, 64, 409-416. http://dx.doi.org/10.2478/geoca-2013-0028

[75] Nouri, R., Jafari, M.R., Arian, M., Feizi, F. and Afzal, P. (2013) Prospection for Copper Mineralization with Contribution of Remote Sensing, Geochemical and Mineralographical Data in Abhar 1:100,000 Sheet, NW Iran. Archives of Mining Sciences, 58, 1071-1084. http://dx.doi.org/10.2478/amsc-2013-0074

[76] Nouri, R., Afzal, P., Arian, M., Jafari, M. and Feizi, F. (2013) Reconnaissance of Copper and Gold Mineralization Us- 
ing Analytical Hierarchy Process in the Rudbar 1: 100,000 Map Sheet, Northwest Iran. Journal of Mining and Metallurgy, 49, 9-19.

[77] Farrokhnia, A.R., Pirasteh, S., Pradhan, B., Pourkermani, M. and Arian, M. (2011) A Recent Scenario of Mass Wasting and Its Impact on the Transportation in Alborz Mountains, Iran Using Geo-Information Technology. Arabian Journal of Geosciences, 4, 1337-1349. http://dx.doi.org/10.1007/s12517-010-0238-7

[78] Arian, M. and Nouri, R. (2015) Lineament Tectonics and Mineralization in Tarom Area, North Iran. Open Journal of Geology, 5, 115-124. http://dx.doi.org/10.4236/ojg.2015.53011

[79] Feizi, F. and Arian, M. (2011) The Role of Structural Controllers in Geneses of Copper Deposits in 1:50000 Map of Saiin Qaleh. Journal of Sciences, 21, 1-10.

[80] Arian, M., Qorashi, M. and Ahmadnia, A. (2003) Analysis of Behbahan Shear Zone. Iranian Journal of Geology, 1, $1-4$.

[81] Bahiraee, S, Arian, M., Qorashi, M. and Solgi, M. (2015) The Movement Potential Evaluation of the Mosha Fault (the West of Firoozkuh to the Shahrestanak). Geosciences, 24, 123-126.

[82] Bagha, N., Ghorashi, M., Arian, M., Pourkermani, M. and Solgi, A. (2015) Neotectonic Analysis of Mosha-North Tehran Fault Zone, Based on Morphotectonic Features, Central Alborz, Northern Iran. Geosciences, 24, 41-52.

[83] Mosavi, E. and Arian, M. (2015) Neotectonics of Kashaf Rud River, NE Iran by Modified Index of Active Tectonics (MIAT). International Journal of Geosciences, 6, 776-794. http://dx.doi.org/10.4236/ijg.2015.67063

[84] Nouri, R. and Arian, M. (2015) Structural Control on the Distribution of Hydrothermal Alteration Zones and Mineralization in Dastjerdeh Area Based on Remote Sensing Data, NW Iran. Bulletin of the Georgian National Academy of Sciences, 9, 79-86.

[85] Sistanipour, A. and Arian, M. (2015) Geometric Analysis of Davaran Fault System, Central Iran. Open Journal of Geology, 5, 458-469. http://dx.doi.org/10.4236/ojg.2015.56043

[86] Nazemi, M., Ghorashi, M., Ghassemi, M.R. and Arian, M. (2015) Morphotectonics Features of Alluvial Fans Associated with Active Tectonics (Shotori Mountains, East of Tabas-Central Iran). Geosciences, 24, 91-100.

[87] Alizadeh, H. and Arian, M. (2015) Rule of Structural Factors in Formation of Porphyry Copper Deposits in South Western Part of Kerman Area, Iran. Open Journal of Geology, 5, 489-498. http://dx.doi.org/10.4236/ojg.2015.57045

[88] Javadi Mosavi, E. and Arian, M. (2015) Neotectonics of Tabas Area, Central Iran by Index of Active Tectonics (IAT). Open Journal of Geology, 5, 209-223. http://dx.doi.org/10.4236/ojg.2015.54019

[89] Jamalian Daryani, N., Arian, M. and Rashidnezhad Omran, N. (2015) Tectonics and Mineralization of Copper in the Ardestan-Kahang Area, Central Iran by Remote Sensing. Open Journal of Geology, 5, 188-196. http://dx.doi.org/10.4236/ojg.2015.54017

[90] Arian, M. and Pourkermani, M. (2001) Rivers Morphology and Active Tectonic (Reviewing the Current Status of Ghezel Ozon River in the Province of Zanjan). 5th Conference of Geological Society of Iran, Tehran, 28-30 August 2001, 556.

[91] Eshghi, Z., Arian, M. and Pourkermani, M. (2012) Structural Investigation on the Lak Mining Area (Bueen Zahra) Based on Remote Sensing, Used for Its Mineralization. Journal of the Earth, 6, 145-155.

[92] Arian, M., Toudeshki, V.H. and Noroozpour, H. (2011) Active Tectonics of Qezel Ozan River Basin, NW Iran. Journal of Applied Environmental and Biological Sciences, 1, 291-295.

[93] Alizadeh, H., Arian, M., Lotfi, M., Ghorashi, M. and Ghorbani, M. (2015) Determination of Porphyry Copper Deposit Locations Using Photo Lineament Factor in Northern Parts of the Dehaj-Sardoiyeh Belt. Geosciences, 24, 247-252.

[94] Housini Toudeshki, V., Pourkermani, M., Arian, M. and Khosrotehrani, K.H. (2011) Influence of Structures on the Ghezel Ozan River. Geosciences, 21, 55-60.

[95] Housini Toudeshki, V. and Arian, M. (2011) Morphotectonic Analysis in the Ghezel Ozan River Basin, NW Iran. Journal of Geography and Geology, 3, 258-260. http://dx.doi.org/10.5539/jgg.v3n1p258

[96] Arian, M. (2015) Seismotectonic-Geologic Hazards Zoning of Iran. Earth Sciences Research Journal, 19, 7-13. http://dx.doi.org/10.15446/esrj.v19n1.40664

[97] Arian, M., Pourkermani, M., Sistanipour, A. and Noroozpour, H. (2011) Kinematic Significance of Fold- and FaultRelated Fracture Systems in the Rafsanjan’s Northeast Highlands (Central Iran). Journal of Basic and Applied Scientific Research, 1, 3398-3406.

[98] Arian, M., Pourkermani, M., Sistanipour, A. and Noroozpour, H. (2011) Seismicity and Fault Segmentation of Bafq-Baghin Fault System (Central Iran). Journal of Applied Environmental and Biological Sciences, 1, 382-396.

[99] Javadi Mosavi, E., Arian, M., Ghorashi, M. and Nazemi, M. (2012) Measurements of Geomorphic Indices in Tabas Area. Journal of the Earth, 7, 213-225. 
[100] Arian, M. (2010) Earthquake-Fault Hazard Investigations in the Kerman Quadrangle. Journal of Sciences, 19, $176-182$.

[101] Cox, R.T. (1994) Analysis of Drainage Basin Symmetry as a Rapid Technique to Identify Areas of Possible Quaternary Tilt Block Tectonics: An Example from the Mississippi Embayment. Geological Society American Bulletin, 106, 571-581. http://dx.doi.org/10.1130/0016-7606(1994)106<0571:AODBSA>2.3.CO;2

[102] Salvany, J.M. (2004) Tilting Neotectonics of the Guadiamar Drainage Basin, SW Spain. Earth Surface Processes and Landforms, 29, 145-160. http://dx.doi.org/10.1002/esp.1005

[103] Bagha, N., Arian, M., Ghorashi, M., Pourkermani, M., El Hamdouni, R. and Solgi, A. (2014) Evaluation of Relative Tectonic Activity in the Tehran Basin, Central Alborz, Northern Iran. Geomorphology, 213, 66-87. http://dx.doi.org/10.1016/j.geomorph.2013.12.041 